\title{
Impact of different cut types on the quality of fresh-cut potatoes during storage
}

\section{Impacto de tipos diferentes de cortes na qualidade de batata crua durante estocagem}

\author{
Muhammad Irfan ${ }^{1}$, Muhammad Inam-Ur-Raheem ${ }^{1}$, Rana Muhammad Aadil ${ }^{1}$ (D), \\ Rameesha Nadeem ${ }^{2}$, Umair Shabbir ${ }^{2 *}$ (D), Ahsan Javed ${ }^{2}$ \\ ${ }^{1}$ University of Agriculture Faisalabad, National Institute of Food Science and Technology, Faisalabad/Punjab - \\ Pakistan \\ ${ }^{2}$ Government College University Faisalabad (GCUF), Institute of Home and Food Science, Faisalabad/Punjab - \\ Pakistan
}

${ }^{*}$ Corresponding Author: Umair Shabbir, Government College University Faisalabad, Institute of Home and Food Science, +38000, Faisalabad/Punjab - Pakistan, e-mail: umair336@gmail.com

Cite as: Irfan, M., Inam-Ur-Raheem, M., Aadil, R. M., Nadeem, R., Shabbir, U., \& Javed, A. (2020). Impact of different cut types on the quality of fresh-cut potatoes during storage. Brazilian Journal of Food Technology, 23 e2019005. https://doi.org/10.1590/1981-6723.00519

\begin{abstract}
Fresh-cut vegetables can be minimally processed through cleaning/washing, trimming, peeling, slicing and dicing, followed by packaging and cold storage. This study aimed to verify the effect of different cuts on the quality and shelf life of fresh-cut potato. Different cut types, such as slices, dices, cubes and wedges, were selected for this study to evaluate the shelf-life response of potatoes. Potato pieces of these different shapes were treated with calcium chloride, citric acid, and potassium metabisulfite ( $3 \%, 2 \%$ and $0.3 \%$, respectively), stored in plastic boxes at $4{ }^{\circ} \mathrm{C}$ for 60 days, and then physicochemically (firmness $(\mathrm{N})$, weight loss $(\mathrm{WL})$, $\mathrm{pH}$, titratable acidity $(\mathrm{TA})$, total soluble solids (TSS), and ascorbic acid (AA) content analyses) and microbiologically assessed. The best results were observed for the dice cut type, which showed minimal changes in TSS (5.31\%), pH (5.65), TA (0.34\%), WL (9.04\%), and AA content (10.86\%). Moreover, the microbial activity of all shapes of potato pieces remained within acceptable limits during cold storage.
\end{abstract}

Keywords: Minimally processed produce; Dices; Shelf life; Acceptability; Cold storage.

\begin{abstract}
Resumo
Vegetais minimamente processados podem ser preparados a partir de várias etapas de processamento como lavagem, toalete, retirada da casca, corte, seguidas por embalagem e armazenamento refrigerado. $O$ presente estudo objetivou determinar os efeitos de diferentes na qualidade e na vida-de-prateleira de batata minimamente processada. Tipos diferentes de corte, tais como fatias, dadinhos, cubos e cunhas, foram selecionados para este estudo, com intuito de avaliar seu efeito na vida-de-prateleira das batatas. Batatas cortadas em diferentes formatos foram tratadas com cloreto de cálcio, ácido cítrico e metabissulfito de potássio (3\%, 2\% e 0,3\%), armazenadas a $4{ }^{\circ} \mathrm{C}$ por 60 dias e depois avaliadas por análises físico-químicas (firmeza, perda de peso, pH, acidez titulável, sólidos solúveis totais (SST) e conteúdo de ácido ascórbico (AA)) e microbiológicas. Os melhores resultados foram obtidos para o corte em pequenos cubos, com mudanças mínimas em SST $(5,31 \%)$, pH $(5,65)$, acidez titulável $(0,34 \%)$, perda de peso $(9,04 \%)$ e conteúdo de AA (10,86\%). A atividade microbiana em todos os cortes de batata permaneceu dentro de limites aceitáveis, durante o armazenamento refrigerado.
\end{abstract}

Palavras-chave: Vegetais minimamente processados; Corte; Vida-de-prateleira; Aceitabilidade; Armazenamento. 


\section{Introduction}

Fruits and vegetables are essential components of the human diet, and their consumption has consistently been associated with health improvement (Ramos et al., 2013). Potato (Salonum tuberosum), which belongs to the Solanaceae family, genus Salonum, is rich in potassium, iron, copper, manganese, phosphorus, thiamine, vitamin C, pyridoxine, dietary fiber, and niacin. Moreover, some phytonutrients, e.g., carotenoids, flavonoids and phenolic compounds, are also present in potato tubers. Considering this nutritional profile, potato is highly beneficial against a number of conditions, such as cardiovascular diseases (Crozier et al., 2009), and shows anti-inflammatory (Kaspar et al., 2011), anticancer, antioxidant, cytotoxic and antitumor (Chung et al., 2016) activity. In Pakistan, potato is widely cultivated in an area of over 186,900 ha, with annual production estimated in 4,446.5 million tons (Government of Pakistan, 2018).

The demand for fresh-cut potatoes has been increasing globally, but fresh-cut potatoes are prone to browning after cutting, like many other fruits and vegetables (You et al., 2012; Wang et al., 2015). These cutting processes cause wounding stress that can accelerate the deterioration processes, such as water loss, oxidative browning, tissue softening, and development of off-flavors, thus limiting the shelf life of fresh-cut products (Hodges \& Toivonen, 2008). Browning may be a symptom of an ongoing degenerative process such as damaging of cell compartmentalization (Marangoni et al., 1996), or of polyphenol oxidase (PPO) activity on the phenolic compounds (substrates), in which the enzymes are activated when the cut surface comes into contact with oxygen (Wang et al., 2015). Cantwell \& Suslow (2002) showed that the problem of cell rupture arises after cutting during minimal processing, thus triggering biochemical reactions in the fresh-cut produce, resulting in short shelf life.

Reduction in produce postharvest losses is a main concern, and numerous techniques to tackle this problem have been established over the years. These techniques (irradiation, hypobaric storage, high and low temperatures, modified and controlled atmospheres, dipping in anti-browning (AA) and antibacterial (calcium chloride) solutions, and fresh-cut technology) not only improve the quality, but also reduce the postharvest losses of agricultural products (Albanese et al., 2007; Wu et al., 2012).

The demand for fresh-cut products has been increasing because of their freshness, convenience, and high nutritional quality (Allende et al., 2006). Fresh-cut fruits and vegetables are commonly prepared through cleaning/washing, trimming, peeling, shredding/slicing and dicing, followed by packaging and cold storage (Baskaran et al., 2007). Minimal processing of fruits and vegetables is carried out in order to increase their shelf life by controlling enzymatic browning. This study was designed to analyze the cut-type (slices, cubes, dices, and wedges) effects on the quality and shelf life of potatoes stored at $4{ }^{\circ} \mathrm{C}$, as well as to verify these effects on the physicochemical characteristics and microbial activity of this product.

\section{Material and methods}

Ripe potatoes were purchased from the vegetable market in Faisalabad, Pakistan, and then sorted, graded, washed/cleaned, trimmed, peeled, and cut into different shapes, namely, $T_{1}$ (slices), $T_{2}$ (cubes), $T_{3}$ (dices), and $\mathrm{T}_{4}$ (wedges). These samples of different shapes were treated using a solution containing $\mathrm{CaCl}_{2}$ (firming agent: firmness is increased when calcium ions produce bridges between the cell wall and pectin in fruits and vegetables), citric acid (enhances shelf life and reduces browning in fresh-cut potatoes), and potassium metabisulfite (as a preservative) at $3 \%, 2 \%$, and $0.3 \%$, respectively, packed in plastic boxes, stored at $4{ }^{\circ} \mathrm{C}$, and evaluated every 12 days for 60 days.

Firmness (N) of the potatoes was determined using a TA-XT plus texture analyzer (Stable Micro System, UK) according to the methodology described by Rahman \& Al-Farsi (2005). Titratable acidity (TA) and weight loss (WL) were determined using the methodology by (Argañosa et al., 2008), and pH was assessed according to the methodology by Cheng et al. (2007). Total soluble solids (TSS) of the potato pieces were determined using a hand-held refractometer (Abbe model 10450) as described by 
Dong et al. (2001). Ascorbic acid (AA) content was determined by the 2,6-dichlorophenol dye titration method as found in the AOAC (Association of Official Analytical Chemists, 2006), and total phenolic compound (TPC) contents were assessed using the methodology by (Wojdyło et al., 2007). Microbiological evaluation was carried out according to Morais \& Arganosa (2010).

\section{Statistical analysis}

The data obtained for each parameter were submitted to statistical factorial analysis of variance (two-way ANOVA) according to Steel et al. (1997), and significant ranges were further compared with application of the Least Significant Difference (LSD) means test, and processed using the Statistic 8.1 software.

\section{Results and discussion}

\subsection{Firmness (N)}

Firmness of vegetables and fruits is derived from their turgor pressure, and the composition of individual plant cell walls and the middle lamella "glue" that holds individual cells together (Barrett et al., 2010). Potato $\mathrm{N}$ is reduced due to water loss and the softening of tissues caused by starch hydrolysis. These softening processes can be controlled by increasing the concentration of calcium salts. In the present study, an increasing trend in firmness of the fresh-cut potato was observed during the first 12 days, followed by a decrease up to 60 days. The largest decrease in $\mathrm{N}$ (from 1.93 to $0.75 \mathrm{~N}$ ) was observed in T1 (slices), whereas the smallest decrease $\left(1.95-1.25 \mathrm{~N}\right.$ ) was found in $\mathrm{T} 3$ (dices), up to the $60^{\text {th }}$ day of cold storage (Figure 1). Similarly, Nourian et al. (2003) observed that potato N decreased with different storage temperatures and Zhao et al. (2017) verified an increasing trend for hardness in cooked potato slices pretreated with $0.8 \%$ acetic acid.

\section{FIRMNESS}

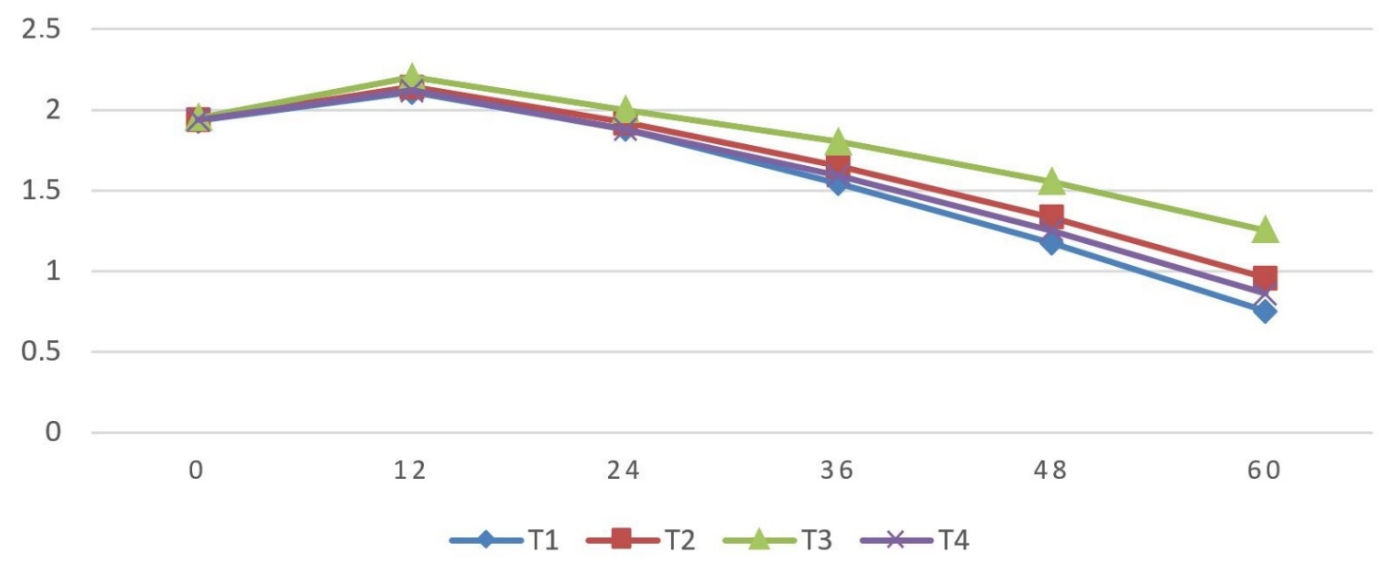

Figure 1. Firmness $(\mathrm{N})$ of the fresh-cut potatoes stored at $4{ }^{\circ} \mathrm{C}$ for 60 days. Cut types: $\mathrm{T}_{1}=$ slices, $\mathrm{T}_{2}=$ cubes, $\mathrm{T}_{3}=$ dices, and $\mathrm{T}_{4}=$ wedges. The treatments consisted in dipping the fresh-cut potatoes in a solution containing $3 \%$ calcium chloride, $2 \%$ citric acid, and $0.3 \%$ potassium metabisulfite.

\subsection{Titratable Acidity (TA) and pH}

In general, TA decreases and $\mathrm{pH}$ increases with the ripening of vegetables and fruits during the storage period, and after peeling and cutting, the respiration rate increases and the TA decreases (Hui, 2006). In the fresh-cut potato samples assessed, the largest decrease in TA (0.96-0.05) was observed in $\mathrm{T}_{1}$ (slices), whereas 
the smallest decrease (0.96-0.34) was verified in $\mathrm{T}_{3}$ (dices), during the 60 days of cold storage (Table 1 ). A decreasing trend in TA was also observed by Rocha \& Morais (2003) in fresh-cut apple slices, and Li et al. (2017) reported that the TA of fresh-cut pitaya fruit decreased during the storage period. A slight increase in $\mathrm{pH}$ (4.74-5.65) was found in $\mathrm{T}_{3}$ (dices) and a greater increase (4.75-6.04) was observed in $\mathrm{T}_{1}$ (slices), during the 60 days of cold storage (Table 1). Similarly, an increasing trend in $\mathrm{pH}$ was observed by Rocha \& Morais (2003) in fresh-cut apple slices, and (Bico et al., 2009) reported increased $\mathrm{pH}$ and decreased TA over time in chemically treated fruit maintained in a controlled atmosphere.

\subsection{Total Soluble Solids (TSS)}

Starch hydrolysis softens the potato tissue during storage, with starch being converted into glucose with the action of enzymes. The smallest increase in TSS (from 4.36 to $5.31 \%$ ) was observed in $\mathrm{T}_{3}$ (dices), whereas the largest increase (4.38-5.75\%) was found in $\mathrm{T}_{1}$ (slices), during the entire cold storage period (Table 1). Song et al. (2013) claimed that fresh-cut potato treated with AA solution showed an increasing trend in TSS, and Nourian et al. (2003) observed that the TSS of potato increased during storage.

\subsection{Weight Loss (WL)}

The quality of minimally processed products is affected by respiration and water loss. The crispiness and turgor of minimally processed fruit decreases in the absence of internal tissue and cuticle (Beaulieu \& Gorny, 2002). During the 60 days of cold storage, the largest WL (from 0 to 11.47\%) was observed in $T_{1}$ (slices) and the smallest (0 to 9.04\%) was verified in $T_{3}$ (dices) due to the smaller surface area exposed to the air (Table 1). Bico et al. (2009) found that chemically dipped fresh-cut banana showed less WL than the untreated samples, and Song et al. (2013), studying fresh-cut potato treated with an anti-browning agent, reported increased WL during storage.

\subsection{Ascorbic Acid (AA) content}

During long-term storage, the AA content decreases in minimally processed vegetables and fruits (Supapvanich et al., 2011). In the present study, the smallest decrease in the AA content (from 18.56 to $10.86 \mathrm{mg} / 100 \mathrm{~g}$ ) was observed in $\mathrm{T}_{3}$ (dices) and the largest (18.49-6.49 $\mathrm{mg} / 100 \mathrm{~g}$ ) in $\mathrm{T}_{1}$ (slices), during the 60 days of cold storage (Table 1). In general, AA content decreases after cutting, especially during extended storage periods. Ascorbic acid is converted to dehydroascorbic acid during storage in the presence of heat, metals, and oxygen (Supapvanich et al., 2011). Song et al. (2013) suggested that fresh-cut potato treated with an anti-browning agent $(0.1 \%$ AA for $60 \mathrm{~min})$ maintained its quality due to the action of this agent, and Nourian et al. (2003) observed decreasing AA contents in potato stored at different temperatures.

\subsection{Total Phenolic Compound (TPC) contents}

The phenolic compounds responsible for the color of vegetables and fruits can be used as substrates by oxidative enzymes. Such enzymes can cause many problems in fruits and vegetables, such as browning, softening and oxidation, when polyphenol oxidase (PPO) and peroxidase (POD) are present in sufficient amounts. In the early stages of cold storage, the TPC of the fresh-cut potato samples increased, but subsequently decreased. The lowest TPC $(154.00 \mu \mathrm{g} / \mathrm{g})$ in the fresh-cut potato samples assessed was found in $\mathrm{T}_{2}$ (cubes) after 0 days of storage, whereas the highest TPC $(198.00 \mu \mathrm{g} / \mathrm{g})$ was observed in $\mathrm{T}_{3}$ (dices) after 48 days of storage (Figure 2). Wang et al. (2015) observed an increasing trend for the TPC of minimally processed potatoes and Furrer et al. (2017) also reported a similar trend in different potato varieties during storage, corroborating the findings of the present study. 


\section{TPC}

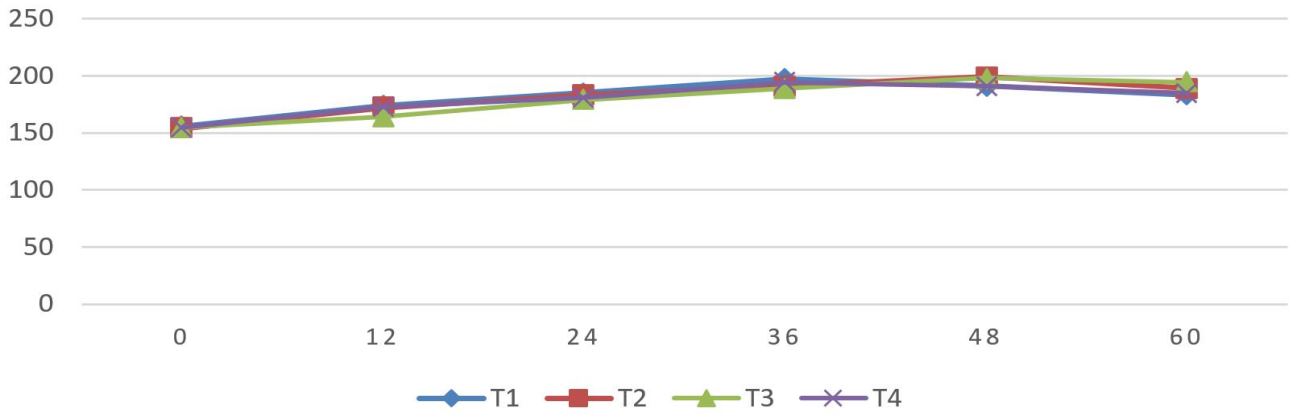

Figure 2. Total phenolic compound (TPC) contents of fresh-cut potatoes stored at $4{ }^{\circ} \mathrm{C}$ for 60 days. Cut types:

$\mathrm{T}_{1}=$ slices, $\mathrm{T}_{2}=$ cubes, $\mathrm{T}_{3}=$ dices, and $\mathrm{T}_{4}=$ wedges. The treatments consisted in dipping the fresh-cut potatoes in a solution containing $3 \%$ calcium chloride, metabisulfite $2 \%$ citric acid, and $0.3 \%$ potassium metabisulfite.

Table 1. Interactive cut-type (slices, cubes, dices and wedges) effects for fresh-cut potato stored at $4{ }^{\circ} \mathrm{C}$ for 60 days.

\begin{tabular}{|c|c|c|c|c|c|c|c|}
\hline Parameter & Treatment & $\mathbf{0}$ & 12 & 24 & 36 & 48 & 60 \\
\hline \multirow{4}{*}{ TA } & $\mathrm{T}_{1}$ (slices) & $0.96^{\mathrm{b}}$ & $0.89^{\mathrm{d}}$ & $0.75^{\mathrm{h}}$ & $0.58^{1}$ & $0.31^{\mathrm{q}}$ & $0.05^{\mathrm{t}}$ \\
\hline & $\mathrm{T}_{2}$ (cubes) & $0.97^{\mathrm{ab}}$ & $0.92^{\mathrm{c}}$ & $0.81^{\mathrm{f}}$ & $0.67^{j}$ & $0.45^{\mathrm{n}}$ & $0.22^{\mathrm{r}}$ \\
\hline & $\mathrm{T}_{3}$ (dices) & $0.96^{\mathrm{b}}$ & $0.98^{\mathrm{a}}$ & $0.85^{\mathrm{e}}$ & $0.72^{\mathrm{i}}$ & $0.55^{\mathrm{m}}$ & $0.34^{\mathrm{p}}$ \\
\hline & $\mathrm{T}_{4}$ (wedges) & $0.97^{\mathrm{ab}}$ & $0.90^{\mathrm{d}}$ & $0.77^{\mathrm{g}}$ & $0.61^{\mathrm{k}}$ & $0.37^{\circ}$ & $0.14^{\mathrm{s}}$ \\
\hline \multirow{4}{*}{ pH } & $\mathrm{T}_{1}$ (slices) & $4.75^{\mathrm{s}}$ & $4.89^{p}$ & $5.11^{1}$ & $5.36^{\mathrm{h}}$ & $5.63^{\mathrm{e}}$ & $6.04^{\mathrm{a}}$ \\
\hline & $\mathrm{T}_{2}$ (cubes) & $4.74^{\mathrm{s}}$ & $4.79^{r}$ & $5.04^{\mathrm{n}}$ & $5.25^{\mathrm{j}}$ & $5.50^{\mathrm{g}}$ & $5.84^{\mathrm{c}}$ \\
\hline & $\mathrm{T}_{3}$ (dices) & $4.74^{\mathrm{s}}$ & $4.69^{t}$ & $4.96^{\circ}$ & $5.14^{\mathrm{k}}$ & $5.37^{\mathrm{h}}$ & $5.65^{\mathrm{d}}$ \\
\hline & $\mathrm{T}_{4}$ (wedges) & $4.74^{\mathrm{s}}$ & $4.85^{\mathrm{q}}$ & $5.08^{\mathrm{m}}$ & $5.30^{\mathrm{i}}$ & $5.56^{\mathrm{f}}$ & $5.88^{\mathrm{b}}$ \\
\hline \multirow{4}{*}{ TSS } & $\mathrm{T}_{1}$ (slices) & $4.38^{\mathrm{u}}$ & $4.54^{\mathrm{q}}$ & $4.76^{\mathrm{m}}$ & $5.03^{\mathrm{i}}$ & $5.37^{\mathrm{d}}$ & $5.75^{\mathrm{a}}$ \\
\hline & $\mathrm{T}_{2}$ (cubes) & $4.37^{\mathrm{uv}}$ & $4.49^{\mathrm{s}}$ & $4.67^{\circ}$ & $4.90^{\mathrm{k}}$ & $5.17^{\mathrm{g}}$ & $5.54^{\mathrm{c}}$ \\
\hline & $\mathrm{T}_{3}$ (dices) & $4.36^{\mathrm{v}}$ & $4.46^{\mathrm{t}}$ & $4.61^{\mathrm{p}}$ & $4.81^{1}$ & $5.06^{\mathrm{h}}$ & $5.31^{\mathrm{e}}$ \\
\hline & $\mathrm{T}_{4}$ (wedges) & $4.37^{\mathrm{uv}}$ & $4.51^{\mathrm{r}}$ & $4.70^{\mathrm{n}}$ & $4.94^{j}$ & $5.21^{\mathrm{f}}$ & $5.57^{\mathrm{b}}$ \\
\hline \multirow{4}{*}{ WL } & $\mathrm{T}_{1}$ (slices) & $0.00^{\mathrm{u}}$ & $1.76^{\mathrm{q}}$ & $2.67^{\mathrm{m}}$ & $5.87^{\mathrm{i}}$ & $8.44^{\mathrm{e}}$ & $11.47^{\mathrm{a}}$ \\
\hline & $\mathrm{T}_{2}$ (cubes) & $0.00^{\mathrm{u}}$ & $1.65^{\mathrm{s}}$ & $2.35^{\circ}$ & $5.21^{\mathrm{k}}$ & $7.89^{\mathrm{g}}$ & $10.75^{\mathrm{c}}$ \\
\hline & $\mathrm{T}_{3}$ (dices) & $0.00^{\mathrm{u}}$ & $1.50^{\mathrm{t}}$ & $2.05^{\mathrm{p}}$ & $4.65^{1}$ & $6.30^{\mathrm{h}}$ & $9.04^{\mathrm{d}}$ \\
\hline & $\mathrm{T}_{4}$ (wedges) & $0.00^{\mathrm{u}}$ & $1.70^{\mathrm{r}}$ & $2.45^{\mathrm{n}}$ & $5.35^{\mathrm{j}}$ & $7.97^{\mathrm{f}}$ & $10.92^{\mathrm{b}}$ \\
\hline \multirow{4}{*}{$\mathbf{A A}$} & $\mathrm{T}_{1}$ (slices) & $18.49^{\mathrm{b}}$ & $16.89^{\mathrm{f}}$ & $14.19^{\mathrm{k}}$ & $11.39^{\circ}$ & $9.49^{\mathrm{s}}$ & $6.49^{\mathrm{v}}$ \\
\hline & $\mathrm{T}_{2}$ (cubes) & $18.50^{\mathrm{b}}$ & $17.13^{\mathrm{d}}$ & $15.85^{\mathrm{h}}$ & $13.67^{1}$ & $11.21^{\mathrm{p}}$ & $9.35^{\mathrm{t}}$ \\
\hline & $\mathrm{T}_{3}$ (dices) & $18.56^{\mathrm{a}}$ & $17.86^{\mathrm{c}}$ & $16.46^{\mathrm{g}}$ & $14.26^{\mathrm{j}}$ & $12.96^{\mathrm{n}}$ & $10.86^{\mathrm{q}}$ \\
\hline & $\mathrm{T}_{4}$ (wedges) & $18.50^{\mathrm{b}}$ & $17.05^{\mathrm{e}}$ & $15.45^{\mathrm{i}}$ & $13.07^{\mathrm{m}}$ & $10.36^{\mathrm{r}}$ & $8.55^{\mathrm{u}}$ \\
\hline
\end{tabular}

Captions: $\mathrm{T}_{1}=$ slices; $\mathrm{T}_{2}=$ cubes; $\mathrm{T}_{3}=$ dices; $\mathrm{T}_{4}=$ wedges; $\mathrm{TA}=$ titratable acidity; $\mathrm{TSS}=$ total soluble solids; $\mathrm{WL}=$ weight loss; $\mathrm{AA}=$ ascorbic acid content. The treatments consisted in dipping the fresh-cut potatoes in a solution containing $3 \%$ calcium chloride, $2 \%$ citric acid, and $0.3 \%$ potassium metabisulfite. The superscript letters after the values show significant difference within the row.

\subsection{Microbiological analysis}

Microbiological safety is known to be a most crucial factor for the storage of minimally processed foods. It was observed that the shelf life of the minimally processed potatoes evaluated was affected throughout the cold storage period. Senescence and maturity reduces firmness and increases cell wall strength, making produce more vulnerable to microbial attack (Silveira et al., 2013, 2017). The lowest microbial count ( $1.80 \log \mathrm{CFU} / \mathrm{g}$ ) was found in both $\mathrm{T}_{3}$ (dices) and $\mathrm{T}_{2}$ (cubes) after 0 days of storage, whereas the highest count (9.40 $\log \mathrm{CFU} / \mathrm{g}$ ) was observed in $\mathrm{T}_{1}$ (slices) after 60 days of storage (Figure 3). Bico et al. (2009) observed smaller increase in the microbial load when minimally processed banana was treated with different chemicals. Cacace et al. (2002) treated fresh-cut potatoes with different chemicals, such as erythorbic acid $(5 \%)$ and citric acid $(1 \%)$, and reported a decrease in microbial growth with increase in acidity. Silveira et al. (2017) reported increasing microbial counts during storage at $5{ }^{\circ} \mathrm{C}$, a finding compatible with the results of the present study. 


\section{MICROBIAL ACTIVITY}

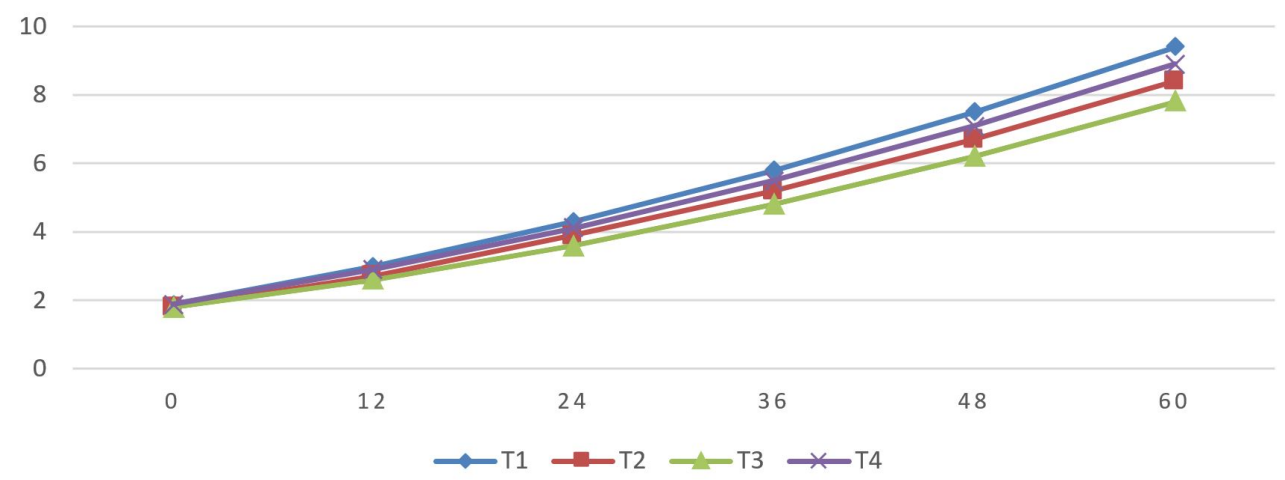

Figure 3. Microbial activity of fresh-cut potatoes stored at $4{ }^{\circ} \mathrm{C}$ for 60 days. $\mathrm{T}_{1}=$ slices, $\mathrm{T}_{2}=$ cubes, $\mathrm{T}_{3}=$ dices, $\mathrm{T}_{4}=$ wedges dipped in a solution containing $3 \%$ calcium chloride, $2 \%$ citric acid, and $0.3 \%$ potassium metabisulfite.

\section{Conclusion}

In conclusion, $T_{3}$ (dices) presented significant positive effects on the shelf life of fresh-cut-potato compared with the other treatments. $\mathrm{T}_{3}$ (dices) maintained the firmness, TSS and $\mathrm{pH}$ of the potatoes, and the AA content decreased slower than in the other treatments. A smaller microbial load was also observed in $\mathrm{T}_{3}$ (dices) during the cold storage period.

\section{References}

Albanese, D., Cinquanta, L., \& Di Matteo, M. (2007). Effects of an innovative dipping treatment on the cold storage of minimally processed Annurca apples. Food Chemistry, 105(3), 1054-1060. PMid:26065770. http://dx.doi.org/10.1016/j.foodchem.2007.05.009

Allende, A., Tomás-Barberán, F. A., \& Gil, M. I. (2006). Minimal processing for healthy traditional foods. Trends in Food Science \& Technology, 17(9), 513-519. http://dx.doi.org/10.1016/j.tifs.2006.04.005

Argañosa, A. C., Raposo, M. F., Teixeira, P. C., \& Morais, A. M. (2008). Effect of cut-type on quality of minimally processed papaya. Journal of the Science of Food and Agriculture, 88(12), 2050-2060. http://dx.doi.org/10.1002/jsfa.3309

Association of Official Analytical Chemists - AOAC. (2006). Official methods of analysis (18th ed.). Washington: AOAC.

Barrett, D. M., Beaulieu, J. C., \& Shewfelt, R. (2010). Color, flavor, texture, and nutritional quality of fresh-cut fruits and vegetables: desirable levels, instrumental and sensory measurement, and the effects of processing. Critical Reviews in Food Science and Nutrition, 50(5), 369-389. PMid:20373184. http://dx.doi.org/10.1080/10408391003626322

Baskaran, R., Devi, A. U., Nayak, C. A., Kudachikar, V. B., Prakash, M. K., Prakash, M., Ramana, K. V., \& Rastogi, N. K. (2007). Effect of low-dose $\mathrm{y}$-irradiation on the shelf life and quality characteristics of minimally processed potato cubes under modified atmosphere packaging. Radiation Physics and Chemistry, 76(6), 1042-1049. http://dx.doi.org/10.1016/j.radphyschem.2006.10.004

Beaulieu, J. C., \& Gorny, J. R. (2002). Fresh-cut fruits. Retrieved in 2007, December 1, from http://www.ba.ars.usda.gov/ hb66/146freshcutfruits.pdf

Bico, S. L., Raposo, M. F., Morais, R. M., \& Morais A. M. (2009). Combined effects of chemical dip and/or carrageenan coating and/or controlled atmosphere on quality of fresh-cut banana. Food Control, 20(5), 508-514.

Cacace J. E., Delaquis P. J., \& Mazza G. (2002). Effect of chemical inhibitors and storage temperature on the quality of freshcut potatoes. Journal of Food Quality, 25(3), 181-195.

Cantwell, M., \& Suslow, T. V. (2002). Postharvest handling systems: fresh-cut fruits and vegetables. In A. A. Kader (Ed.), Postharvest technology of horticultural crops (pp. 445-464). Oakland: University of California, Division of Agriculture and Natural Resources.

Cheng, L. H., Soh, C. Y., Liew, S. C., \& Teh, F. F. (2007). Effects of sonication and carbonation on guava juice quality. Food Chemistry, 104(4), 1396-1401. http://dx.doi.org/10.1016/j.foodchem.2007.02.001

Chung, I. M., Kim, J. K., Jin, Y. I., Oh, Y. T., Prabakaran, M., Youn, K. J., \& Kim, S. H. (2016). Discriminative study of a potato (Solanum tuberosum L.) cultivation region by measuring the stable isotope ratios of bio-elements. Food Chemistry, 212, 48-57. PMid:27374505. http://dx.doi.org/10.1016/j.foodchem.2016.05.161

Crozier, A., Jaganath, I. B., \& Clifford, M. N. (2009). Dietary phenolics: chemistry, bioavailability and effects on health. Natural Product Reports, 26(8), 1001-1043. PMid:19636448. http://dx.doi.org/10.1039/b802662a

Dong, L., Zhou, H. W., Sonego, L., Lers, A., \& Lurie, S. (2001). Ripening of 'Red Rosa' plums: effect of ethylene and 1methylcyclopropene. Functional Plant Biology, 28(10), 1039-1045. http://dx.doi.org/10.1071/PP00149 
Furrer, A., Cladis, D. P., Kurilich, A., Manoharan, R., \& Ferruzzi, M. G. (2017). Changes in phenolic content of commercial potato varieties through industrial processing and fresh preparation. Food Chemistry, 218, 47-55. PMid:27719937. http://dx.doi.org/10.1016/j.foodchem.2016.08.126

Government of Pakistan - GOP. (2018). Retrieved in 2019, May 2, from www.finance.gov.pk/survey_1415.html Hodges, D. M., \& Toivonen, P. M. (2008). Quality of fresh-cut fruits and vegetables as affected by exposure to abiotic stress. Postharvest Biology and Technology, 48(2), 155-162. http://dx.doi.org/10.1016/j.postharvbio.2007.10.016

Hui, Y. H. (2006). Handbook of fruits and fruit processing. USA: John Wiley \& Sons. http://dx.doi.org/10.1002/9780470277737

Kaspar, K. L., Park, J. S., Brown, C. R., Mathison, B. D., Navarre, D. A., \& Chew, B. P. (2011). Pigmented potato consumption alters oxidative stress and inflammatory damage in men. The Journal of Nutrition, 141(1), 108-111. https://doi.org/10.3945/jn.110.128074.

Li, X., Long, Q., Gao, F., Han, C., Jin, P., \& Zheng, Y. (2017). Effect of cutting styles on quality and antioxidant activity in freshcut pitaya fruit. Postharvest Biology and Technology, 124, 1-7. http://dx.doi.org/10.1016/j.postharvbio.2016.09.009

Marangoni, A. G., Palma, T., \& Stanley, D. W. (1996). Membrane effects in postharvest physiology. Postharvest Biology and Technology, 7(3), 193-217. http://dx.doi.org/10.1016/0925-5214(95)00042-9

Morais, A. M. M. B., \& Arganosa, A. C. S. J. (2010). Quality during storage of fresh-cut papaya (Carica papaya L.) in various shapes. Philippine Agricultural Scientist Journal, 93, 88-96.

Nourian, F., Ramaswamy, H. S., \& Kushalappa, A. C. (2003). Kinetics of quality change associated with potatoes stored at different temperatures. Lebensmittel-Wissenschaft + Technologie, 36(1), 49-65. http://dx.doi.org/10.1016/S00236438(02)00174-3

Rahman, M. S., \& Al-Farsi, S. A. (2005). Instrumental texture profile analysis (TPA) of date flesh as a function of moisture content. Journal of Food Engineering, 66(4), 505-511. http://dx.doi.org/10.1016/j.jfoodeng.2004.04.022

Ramos, B., Miller, F. A., Brandão, T. R., Teixeira, P., \& Silva, C. L. (2013). Fresh fruits and vegetables - an overview on applied methodologies to improve its quality and safety. Innovative Food Science \& Emerging Technologies, 20, 1-5. https://doi.org/10.1016/j.ifset.2013.07.002.

Rocha, A. M., \& Morais, A. M. (2003). Shelf life of minimally processed apple (cv. Jonagored) determined by colour changes. Food Control, 14(1), 13-20. http://dx.doi.org/10.1016/S0956-7135(02)00046-4

Silveira, A. C., Aguayo, E., \& Artés, F. (2013). The suitability of three Galia melon cultivars and different types of cuts for the fresh-cut industry. Journal of the Science of Food and Agriculture, 93(15), 3826-3831. PMid:23860939. http://dx.doi.org/10.1002/jsfa.6306

Silveira, A. C., Oyarzun, D., Sepulveda, A., \& Escalona, V. (2017). Effect of genotype, raw-material storage time and cut type on native potato suitability for fresh-cut elaboration. Postharvest Biology and Technology, 128, 1-10.

http://dx.doi.org/10.1016/j.postharvbio.2017.01.011

Song, H. J., Kwon, O. Y., Kang, B. H., Hur, S. S., Lee, D. S., Lee, S. H., Kang, I. K., \& Lee, J. M. (2013). Change in quality attributes of fresh-cut potatoes with heat and browning inhibitor treatment during storage. Korean Journal of Food Preservation, 20(3), 386-393. http://dx.doi.org/10.11002/kjfp.2013.20.3.386

Steel, R., Torrie, J. H., \& Dickey, D. (1997). Principles and procedures of statistics. A biometrical approach (3 ${ }^{\text {rd }}$ ed.). New York: McGraw Hill Book Co. Inc.

Supapvanich, S., Pimsaga, J., \& Srisujan, P. (2011). Physicochemical changes in fresh-cut wax apple (Syzygium samarangense [Blume] Merrill \& LM Perry) during storage. Food Chemistry, 127(3), 912-917. PMid:25214078. http://dx.doi.org/10.1016/j.foodchem.2011.01.058

Wang, Q., Cao, Y., Zhou, L., Jiang, C. Z., Feng, Y., \& Wei, S. (2015). Effects of postharvest curing treatment on flesh colour and phenolic metabolism in fresh-cut potato products. Food Chemistry, 169, 246-254. PMid:25236223. http://dx.doi.org/10.1016/j.foodchem.2014.08.011

Wojdyło, A., Oszmiański, J., \& Czemerys, R. (2007). Antioxidant activity and phenolic compounds in 32 selected herbs. Food Chemistry, 105(3), 940-949. http://dx.doi.org/10.1016/j.foodchem.2007.04.038

Wu, Z. S., Zhang, M., \& Wang, S. (2012). Effects of high pressure argon treatments on the quality of fresh-cut apples at cold storage. Food Control, 23(1), 120-127. http://dx.doi.org/10.1016/j.foodcont.2011.06.021

You, Y., Jiang, Y., Sun, J., Liu, H., Song, L., \& Duan, X. (2012). Effects of short-term anoxia treatment on browning of fresh-cut Chinese water chestnut in relation to antioxidant activity. Food Chemistry, 132(3), 1191-1196. PMid:29243600. http://dx.doi.org/10.1016/j.foodchem.2011.11.073

Zhao, W., Shehzad, H., Yan, S., Li, J., \& Wang, Q. (2017). Acetic acid pretreatment improves the hardness of cooked potato slices. Food Chemistry, 228, 204-210. PMid:28317714. http://dx.doi.org/10.1016/j.foodchem.2017.01.156

Funding: None. 